\title{
Structural Evaluation on Sugarcane Bagasse Treated Using Sodium and Calcium Hydroxide
}

\author{
Juliana Anggono ${ }^{1, *}$, Hariyati Purwaningsih ${ }^{2}$, Suwandi Sugondo ${ }^{1}$, \\ Steven Henrico ${ }^{1}$, Sanjaya Sewucipto ${ }^{1}$, and Jay Patel $^{3}$ \\ ${ }^{1}$ Mechanical Engineering Department, Petra Christian University, Surabaya 60236, Indonesia \\ ${ }^{2}$ Materials and Metallurgical Engineering Department, Sepuluh Nopember Institute of Technology, \\ Surabaya 60111, Indonesia \\ ${ }^{3}$ School for Engineering of Matter, Transport, and Energy - Arizona State University, Tempe, AZ \\ 85287-6106, USA
}

\begin{abstract}
Greater interest in recent years to the increase demand in using natural fiber reinforcement of polymers is to comply with the increasing stringent international protocols related to climate change and environmental awareness. Many studies have reported the development of renewable and biodegradable agricultural by-products as reinforcement fibers for biocomposites. One of the essential factors in producing strong biocomposites is the properties prepared from the natural fibers which results from the alkali treatment given. This research aims to evaluate the effect of different treatment duration on structural changes on sugarcane after alkali treatment using sodium hydroxide $(\mathrm{NaOH})$ and calcium hydroxide $\left(\mathrm{Ca}(\mathrm{OH})_{2}\right)$ solutions. Calcium hydroxide was used as comparative solution in search for milder and more environmental friendly alkali solution as an alternative solution of $\mathrm{NaOH}$. Fourier Transform Infrared (FTIR) confirmed the major removal of lignin and minor of hemicellulose. It shows that the structure did not change considerably with the additional treatment time. The weight loss measurement after each treatment shows a higher weight loss with the treatment with $\mathrm{NaOH}(40.5 \%$ to $57.75 \%)$ than the weight loss after $\mathrm{Ca}(\mathrm{OH})_{2}$ treatment $(25 \%$ to $46 \%)$. Scanning electron microscope (SEM) observed the morphology changes on the fiber from both treatments.
\end{abstract}

Keywords: Alkali solution, alkali treatment, cellulose, mercerization, natural fibers.

\section{Introduction}

Indonesia is a major producer of agricultural products which the sugarcane is one of the main products with a total production of $28.7 \mathrm{t} \mathrm{yr}^{-1}$ (rank $9^{\text {th }}$ in the world) [1]. Agricultural production inevitably generates residues (by-products) that have limited use. Sugarcane stems consist of three major parts: the pith (5\%), fibers (73\%), and the rind (22\%) [2]. Sugarcane bagasse is the remaining substance (waste) after crushing the canes for sugar. Bagasse is a fibrous residue, one among the three other main byproducts of the sugar industry, i.e. cane tops, filter muds, and molasses. Currently sugarcane bagasse is used as primary energy source as fuel for the boilers in the sugar mills and the remaining is stored. However, the important part of the bagasse as an industrial waste is still underutilized. Added-value compounds that can be produced using bagasse are bioethanol [3-6], proteinenriched animal feed ('single cell protein') [7], and enzymes. Therefore various research

\footnotetext{
* Corresponding author: julianaa@petra.ac.id
} 
works have been done to develop methods for further processing of bagasse to produce fuel and chemicals that offer economic, environmental, and strategic advantages. However, there were relatively fewer studies reporting on obtaining fibers from sugarcane bagasse compared to other agricultural by-products.

Bagasse, as well as other lignocellulosic materials consist of cellulose, hemicelluloses, lignin, and small amounts of extractives and mineral salts. Several research has studied bagasse as a potential resource as a reinforcement element in biocomposites [8-15]. There are a wide ray of applications in building, construction, and automobiles that exist for the fabrication of bagasse based composites. The use of lignocellulosic materials require treatment step. One of the key concerns working with natural fibers used as reinforcement component is their hydrophilic nature. These fibers, therefore, are inherently incompatible with hydrophobic thermoplastics which thereby influences the mechanical bonding with the matrix. Therefore chemical treatments are considered in modifying the fiber properties. Chemical treatments using acid have been successfully applied to sugarcane bagasse fiber $[10,13,16]$. Acids hydrolyze hemicellulose and produce a liquid phase rich in xylose, with minor amounts of lignin derivatives and it has been successfully applied to sugarcane bagasse [17, 18]. The principle of alkali treatment method is the removal of lignin (major loss) whereas cellulose and a part of the hemicelluloses remain in the solid material (minor loss of hemicellulose). Treatment using alkali solution (mercerization) has been proven to be effective for removal of lignin in the fibers therefore enhanced fiber suface adhesion which allowed an effective stress transfer from matrix to fiber. Relatively fewer studies have investigated the surface modification on lignocellulosic fibers obtained from sugarcane baggase. The goal of this current work was to investigate the effect of different treatment time on the structural and morphological modification on bagasse fibers treated with sodium hydroxide $(\mathrm{NaOH})$ and lime or calcium hydroxide $\left(\mathrm{Ca}(\mathrm{OH})_{2}\right)$. Calcium hydroxide was chosen for other alternative solution due to its less hazardous characteristics and low cost. Modification on morphology and structure of modified bagassse fibers after those treatments were studied to evaluate the delignification degree for bagasse fiber performed by both solutions in different time length of treatment ranging from $2 \mathrm{~h}$ to $6 \mathrm{~h}$ at temperature of $60{ }^{\circ} \mathrm{C}$ to $70{ }^{\circ} \mathrm{C}$. Characterization on the untreated and treated fibers was carried out using Fourier Transform Infrared (FTIR) and X-ray diffractometer (XRD) tests to determine the modified structure and chemical composition of the bagasse fibers. Scanning electron microscope (SEM) was used to study the effectiveness of both treatments on morphology changes of bagasse fibers at different treatment time.

\section{Materials and methods}

\subsection{Treatment of bagasse fibers}

The first step in the bagasse preparation was neutralization of the bagasse by soaking in a $70 \%$ ethanol as an effective desinfectant or antiseptic agent for $1 \mathrm{~h}$ to eliminate the stench generated due to bacterial fermentation reaction [19]. A ratio of volume of ethanol (L) to the weight of bagasse $(\mathrm{kg})$ used was $2.5: 1$. The neutralized fibers were drained and dried for $6 \mathrm{~h}$ in air at room temperature. The fibers were then dried in the oven (Memmert type UN450) heated from room temperature to $200{ }^{\circ} \mathrm{C}$ with a holding time of $30 \mathrm{~s}$. Treatment was applied to the dried fibers by soaking the fibers in two different solutions of $10 \% \mathrm{vol}$. $\mathrm{NaOH}$ and $14 \%$ vol. $\mathrm{Ca}(\mathrm{OH})_{2}$ at $60^{\circ} \mathrm{C}$ to $70^{\circ} \mathrm{C}$ for various treatment time of $2 \mathrm{~h}, 4 \mathrm{~h}$, and $6 \mathrm{~h}$. At the end of treatment, bagasse fibers were rinsed couple of times in distilled water and a $\mathrm{pH}$ check was done to ensure they were clean from the alkali solution. Before the rinsed fibers went to the oven for drying, they were dried in air for $6 \mathrm{~h}$ at room temperature. 
Lastly, those fibers were oven dried by increasing the temperature from room temperature to $200^{\circ} \mathrm{C}$ with a holding time of $30 \mathrm{~s}$.

Weight loss measurement on bagasse samples after treatment was carried out aiming to determine the delignification degree of both treatments in different time. The weight loss values obtained could inform the effectiveness of lignin removal during treatment. Bagasse samples were weighed when they were received as wet fibrous residue. Two other weight measurements were performed for oven dried bagasse samples both after neutralization and alkali treatment processes.

\subsection{Characterisation of bagasse fibers}

Dried fibers were examined with XRD (X'pert PRO tipe PANalytical) and FTIR (Thermo Scientific Nicolet model) to analyse the structural changes on the fiber surface after treatment. SEM (FEI type Inspect S50) was used to evaluate the surface morphology of the fibers before and after the alkali treatment in different treatment time. Untreated bagasse fibers were also evaluated to study the structural changes after both treatments.

\section{Results and discussion}

\subsection{Weight loss of sugarcane bagasse after treatments}

The goal of alkali treatment includes the removal of lignin and disruption of the crystalline structure of cellulose. Chemicals used in alkali treatment in this study were sodium and calcium hydroxide. The weight loss obtained after neutralization and oven drying was $42.5 \%$. Apart from the three basic chemical compounds (lignin, hemicellulose, and cellulose) that lignocellulose consists of, water is also present in the complex. Typically, sugarcane bagasse has a moisture content of between $45 \%$ and $55 \%$ on a wet basis [20]. Furthermore, minor amounts of proteins, minerals and other components can be found in the lignocellulose composition as well. Therefore the weight loss of neutralized fibers was mainly due to the loss of water/moisture content after drying. Following the neutralization step, the dried fibers were treatment using sodium and calcium hydroxide for $2 \mathrm{~h}, 4 \mathrm{~h}$, and $6 \mathrm{~h}$. After treated and oven dried, the fibers were weighed to calculate a further weight loss. Figure 1 shows the weight loss after both treatments which increases considerably with the addition of treatment time. Significant loss was measured in $\mathrm{NaOH}$ treated fibers in the range of $40.5 \%$ to $57.75 \%$. This weight loss is higher than the loss observed in the fibers treated using $\mathrm{Ca}(\mathrm{OH})_{2}(25 \%$ to $46 \%)$. This higher loss shows that more efficient lignin removal experienced by bagasse treated in $\mathrm{NaOH}$ than in $\mathrm{Ca}(\mathrm{OH})_{2}$. The weight loss due to $\mathrm{NaOH}$ treatment increased by $60 \%$ during $2 \mathrm{~h}$ treatment time compared with the same duration after $\mathrm{Ca}(\mathrm{OH})_{2}$ treatment. When treatment time was increased from $4 \mathrm{~h}$ to $6 \mathrm{~h}$, the weight loss during $\mathrm{NaOH}$ treatment increased only by $30 \%$ compared with treatment using $\mathrm{Ca}(\mathrm{OH})_{2}$. However the weight loss increment with the additional $2 \mathrm{~h}$ treatment time was noted relatively higher in $\mathrm{Ca}(\mathrm{OH})_{2}$ solution $(10 \%$ to $11 \%)$ than in $\mathrm{NaOH}(4.5 \%$ to $12.75 \%$ ). The action of $\mathrm{Ca}(\mathrm{OH})_{2}$ during treatment is slower compared to sodium hydroxide [21]. 


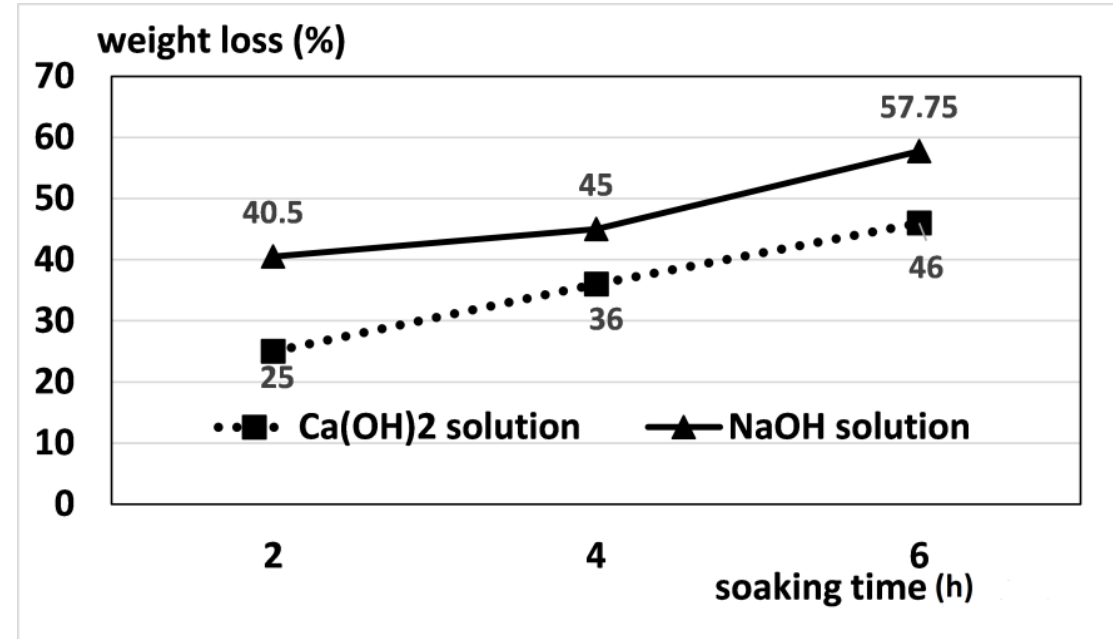

Fig. 1. Weight loss of bagasse fibers after treatment.

Overall, major component removed during $\mathrm{NaOH}$ and $\mathrm{Ca}(\mathrm{OH})_{2}$ treatment was lignin. Hemicellulose removal was contributed as minor loss to the weight loss [21]. FTIR and SEM results support the findings on the weight loss and will be explained in the next section.

\subsection{Characteristics of modified bagasse}

Bagasse is a lignocellulosic material consisting of cellulose $43.8 \%$, hemicellulose $28.6 \%$, lignin $23.5 \%$, ash $1.3 \%$, and other components $2.8 \%$ [19]. Studies performed with different varieties of sugarcane bagasse reported that their main chemical composition does not differ significantly [22].

The major effect of alkali treatment is the removal of lignin from the bagasse. FTIR spectroscopy was used to obtain information about the chemical structure of the bagasse before and after treatment. The FTIR spectra for bagasse after both treatments are shown in Figure $2 \mathrm{a}$ and $2 \mathrm{~b}$. The spectra for untreated fibers were also shown for a comparative study to identify considerable changes in the chemical composition of the bagasse as a consequence of modification due to alkali treatments. The similarity of the FTIR spectra betweeen untreated and treated bagasse fibers was presented in the $4000 \mathrm{~cm}^{-1}$ to $2700 \mathrm{~cm}^{-1}$ region where the $\mathrm{OH}$ and $\mathrm{CH}$ stretching vibrations existed. The FTIR spectra for treated fibers were represented by the spectra of fibers after different treatment time in both $\mathrm{NaOH}$ and $\mathrm{Ca}(\mathrm{OH})_{2}$. The strong broad band observed in the region of $3700 \mathrm{~cm}^{-1}$ to $3000 \mathrm{~cm}^{-1}$ is assigned to different $\mathrm{OH}$ stretching modes and another band in the region of $3000 \mathrm{~cm}^{-1}$ to $2800 \mathrm{~cm}^{-1}$ is attributed to the stretching of asymmetric and symmetric methyl and methylene cellulose groups.

Figure 2c shows a $1800 \mathrm{~cm}^{-1}$ to $800 \mathrm{~cm}^{-1}$ region in the spectra that revealed several bands. The band at $1624 \mathrm{~cm}^{-1}$ is associated with adsorbed water in cellulose and probably some in hemicelluloses. The C-H stretch at $2875 \mathrm{~cm}^{-1}$ is present in both untreated and treated fibers. The $\mathrm{C}-\mathrm{OH}$ bending peaks at $670 \mathrm{~cm}^{-1}$ of cellulose are indicated in all fibers. The obvious differences between the untreated bagasse fibers and treated fibers were noted in the range from $2000 \mathrm{~cm}^{-1}$ to $700 \mathrm{~cm}^{-1}$ (Figure 2a and b). Lignin spectra at $1508 \mathrm{~cm}^{-1}$ and $1233 \mathrm{~cm}^{-1}$ were no longer found in sugar cane fibers that were given shortest treatment time $(2 \mathrm{~h})$, either in $\mathrm{NaOH}$ or $\mathrm{Ca}(\mathrm{OH})_{2}$. Other bands that are generally found in the lignin 
aromatic structure, i.e. at $1598 \mathrm{~cm}^{-1}$ and $1508 \mathrm{~cm}^{-1}$ which attributed to $\mathrm{C}-\mathrm{Ph}$ and $\mathrm{C}=\mathrm{C}$, respectively were not identified after both treatments.

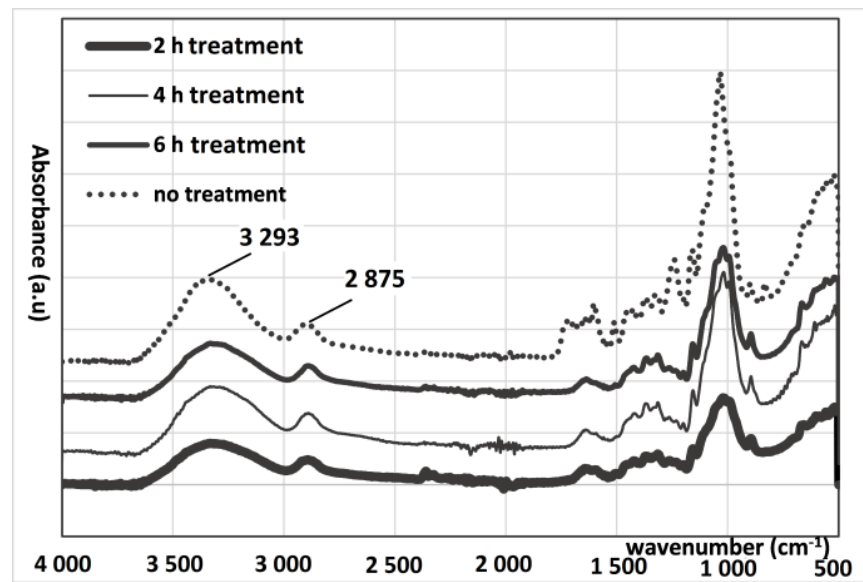

a)

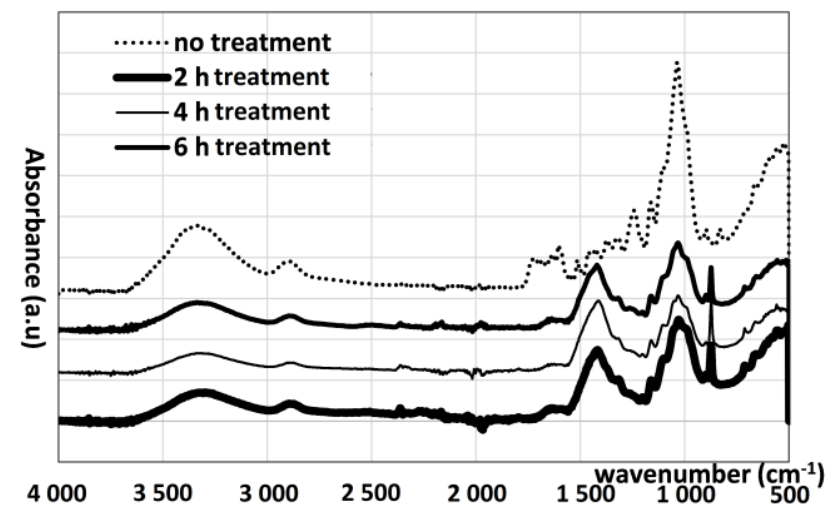

b)

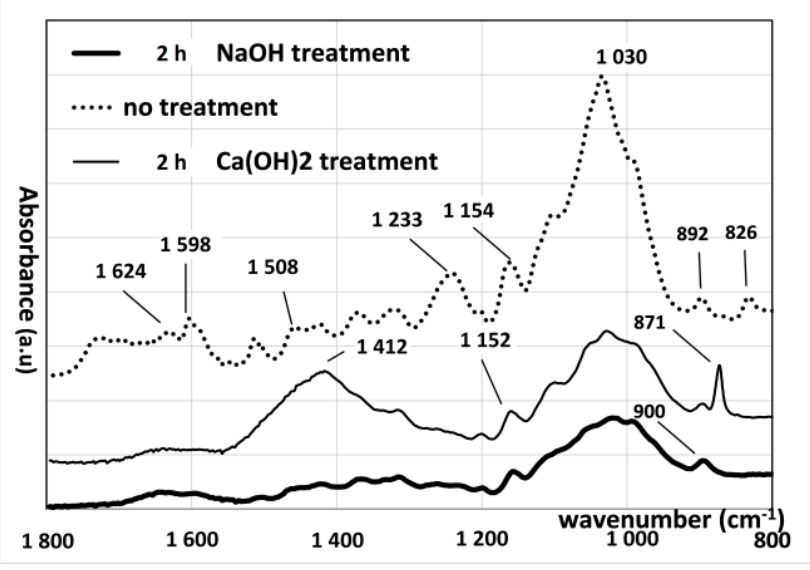

c)

Fig. 2 FTIR spectra of untreated and treated bagasse fibers in the region between $500 \mathrm{~cm}^{-1}$ to 4000 in a) $\mathrm{NaOH}$ and b) $\mathrm{Ca}(\mathrm{OH})_{2}$ and c) in the region between $800 \mathrm{~cm}^{-1}$ to $1800 \mathrm{~cm}^{-1}$ for $2 \mathrm{~h}$ treatment in $\mathrm{NaOH}$ and $\mathrm{Ca}(\mathrm{OH})_{2}$. 
The work of Rezende et al. [23] reported a very efficient alkali treatments using $\mathrm{NaOH}$ solutions with concentration $1 \%$ where up to $85 \%$ lignin fractions were removed from the solid fraction. The peak $1723 \mathrm{~cm}^{-1}$ indicates the carbonyl peak, $\mathrm{C}=\mathrm{O}$ stretching of the acetyl groups of hemicellulose [24, 25] and can be seen in untreated fibers. The disappearance of that peak indicates the removal of hemicellulose from the fiber surface after both treatments for $2 \mathrm{~h}$. Chen et al. [26] reported that treatment with sodium hydroxide causes the disruption of H-bonding in cellulose and hemicellulose, breakage of ester linkages between lignin and xylan, and deprotonation of phenolic groups. As a result, swelling of cellulose and the partial solubilization of hemicellulose and lignin occurs. There is an indication of carbonate peaks in the range of $1500 \mathrm{~cm}^{-1}$ to $1400 \mathrm{~cm}^{-1}$ and $871 \mathrm{~cm}^{-1}$ on the fiber treated using $\mathrm{Ca}(\mathrm{OH})_{2}$ (Figure 2c). XRD analysis and SEM study performed on the bagasse fiber treated using $\mathrm{Ca}(\mathrm{OH})_{2}$ confirmed the existence of carbonate compound.

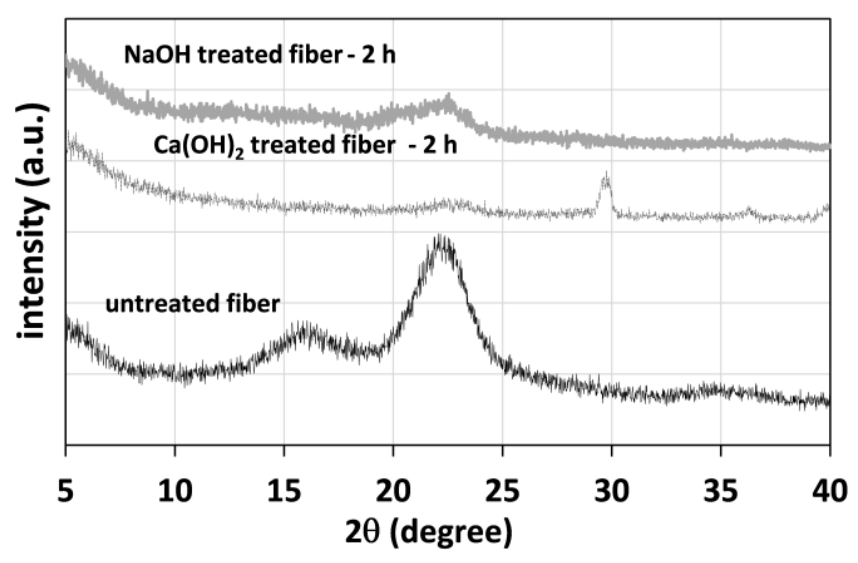

a)

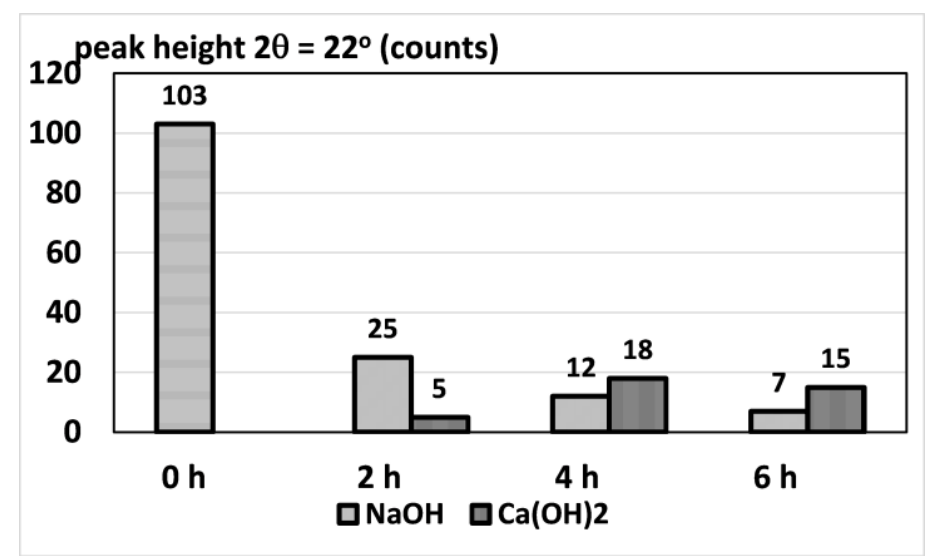

c)

Fig. 3. a) X-ray diffractograms of untreated and treated bagasse fibers in $\mathrm{NaOH}$ and $\mathrm{Ca}(\mathrm{OH})_{2}$ and b) quantitative data of cellulose II after treatment in various treatment time.

Figure 3 shows X-ray diffractograms obtained from untreated and treated fibers both using $\mathrm{NaOH}$ and $\mathrm{Ca}(\mathrm{OH})_{2}$ of $2 \mathrm{~h}$ treatment time. XRD spectra for treated fibers using $\mathrm{NaOH}$ and $\mathrm{Ca}(\mathrm{OH})_{2}$ solutions for $4 \mathrm{~h}$ and $6 \mathrm{~h}$ show similarities with spectra of fibers with $2 \mathrm{~h}$ treatment, therefore only spectra of $2 \mathrm{~h}$ treatment is presented. The diffractogram of 
untreated bagasse fiber shows the main diffraction peaks at $2 \theta$ angles: $15.6^{\circ}$ and $22^{\circ}$ which confirmed the typical cellulose-I structure. Cellulose is a crystalline phase with four different polymorphs of cellulose are known, including cellulose I, II, III, and IV [27]. Alkali treatment in natural cellulose fibers results in the structural transformation from cellulose I (native cellulose) to cellulose II [28, 29]. The major diffraction peak between $22^{\circ}$ and $23^{\circ}$ referred to cellulose (002) crystallographic planes was found in treated fibers in all treatment time but the weak peak at $2 \theta$ angle $15.6^{\circ}$ disappeared (Figure 3a). This structural transformation was observed in the XRD patterns for both treatments which the significant change in diffraction pattern from double peaks as indication of cellulose I to a single peak indicating formation of cellulose II structure.

Figure $3 \mathrm{~b}$ indicates the changes in cellulose transformation on each treatment as function of treatment time. The values were calculated from the peak height of $2 \theta$ angle $22^{\circ}$ to show the values for total cellulose conversion. Treatment with $\mathrm{NaOH}$ results in the decrease of cellulose II with the increase of treatment time. It was reported in the literature that for cellulose with low to moderate degree of polymerization, the maximal solubility occurs with $8 \% \sim 10 \%$ soda solution [30]. However, the results were noticed as opposite to the results from $\mathrm{NaOH}$ treatment in which there was an increase of cellulose II up to $4 \mathrm{~h}$ treatment with $\mathrm{Ca}(\mathrm{OH})_{2}$ before a slightly decreases after $6 \mathrm{~h}$ treatment time. Another peak at $2 \theta$ angle $29.8^{\circ}$ was noted at the bagasse sample treated with $\mathrm{Ca}(\mathrm{OH})_{2}$ in all treatment time. That peak was an indication of the presence of insoluble calcium carbonate that might be obtained from the mixture with the starting powder of calcium hydroxide used and from being recoverable from water by the reaction with carbon dioxide [21].

\subsection{Morphological property of modified bagasse}

To evaluate the effect of alkali treatment on the morphological surface of bagasse fibers, the samples were studied using SEM. Morphological characteristics of fibres before and after treatment were microscopically observed. Figure 4 shows SEM micrographs of unmodified sugarcane fibers, providing the elementary fibrils and bundles are cemented by lignin and pectin intercellular substances. It shows that cellulose fibers are in one piece and intact due to the presence of lignin. The fiber obtained from sugarcane bagasse was shown by parallel stripes and is partially covered with residual material (pith). They are reported to have a length of $2.5 \mathrm{~cm}$ to $20 \mathrm{~cm}$ [2].

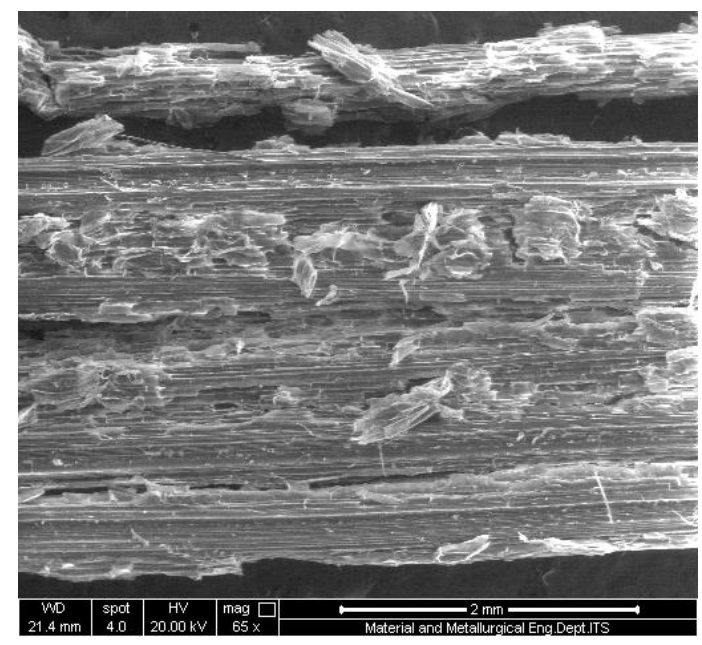

Fig. 4. SEM micrographs of longitudinal view of untreated sugar cane fibers. 

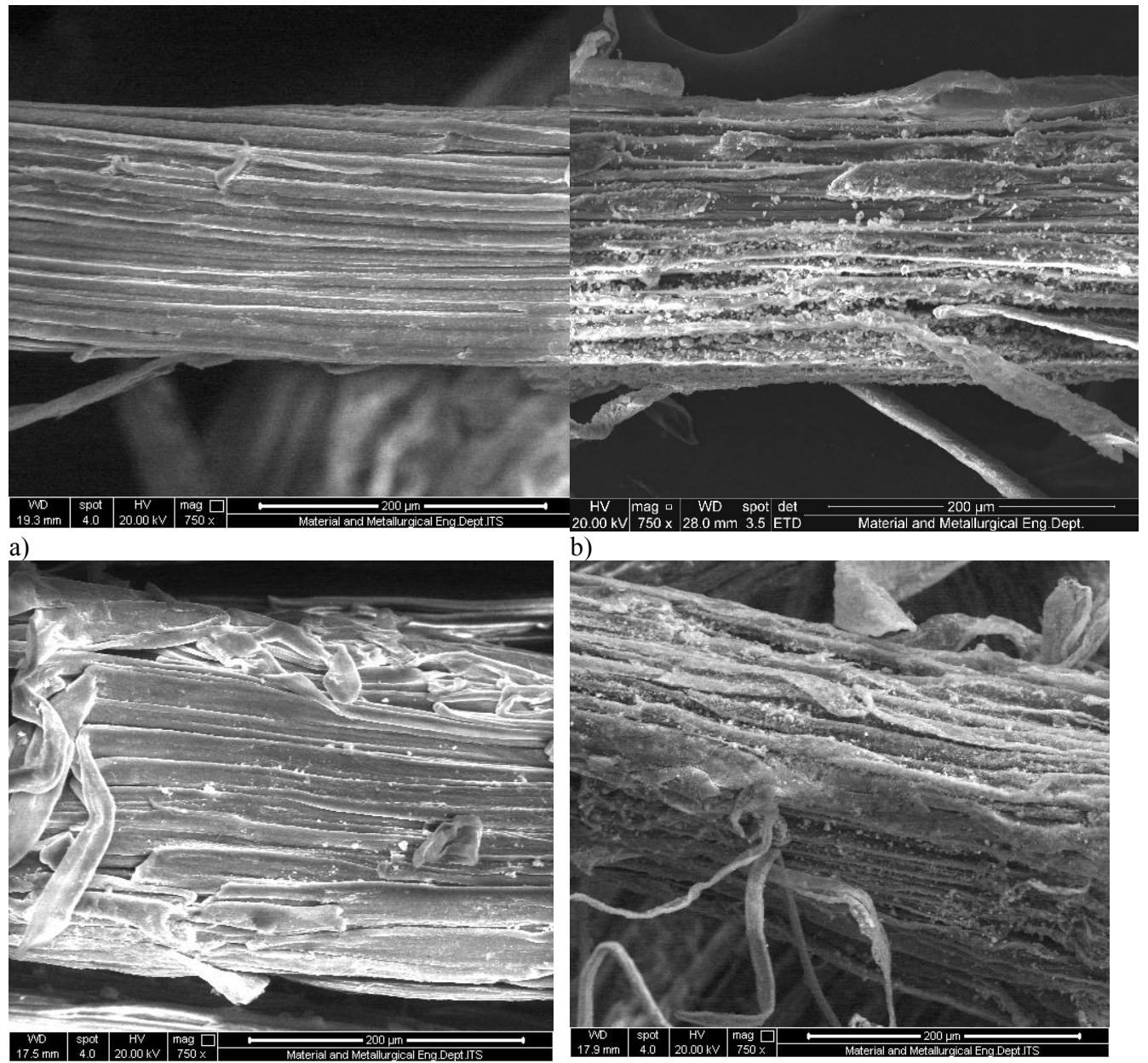

c)
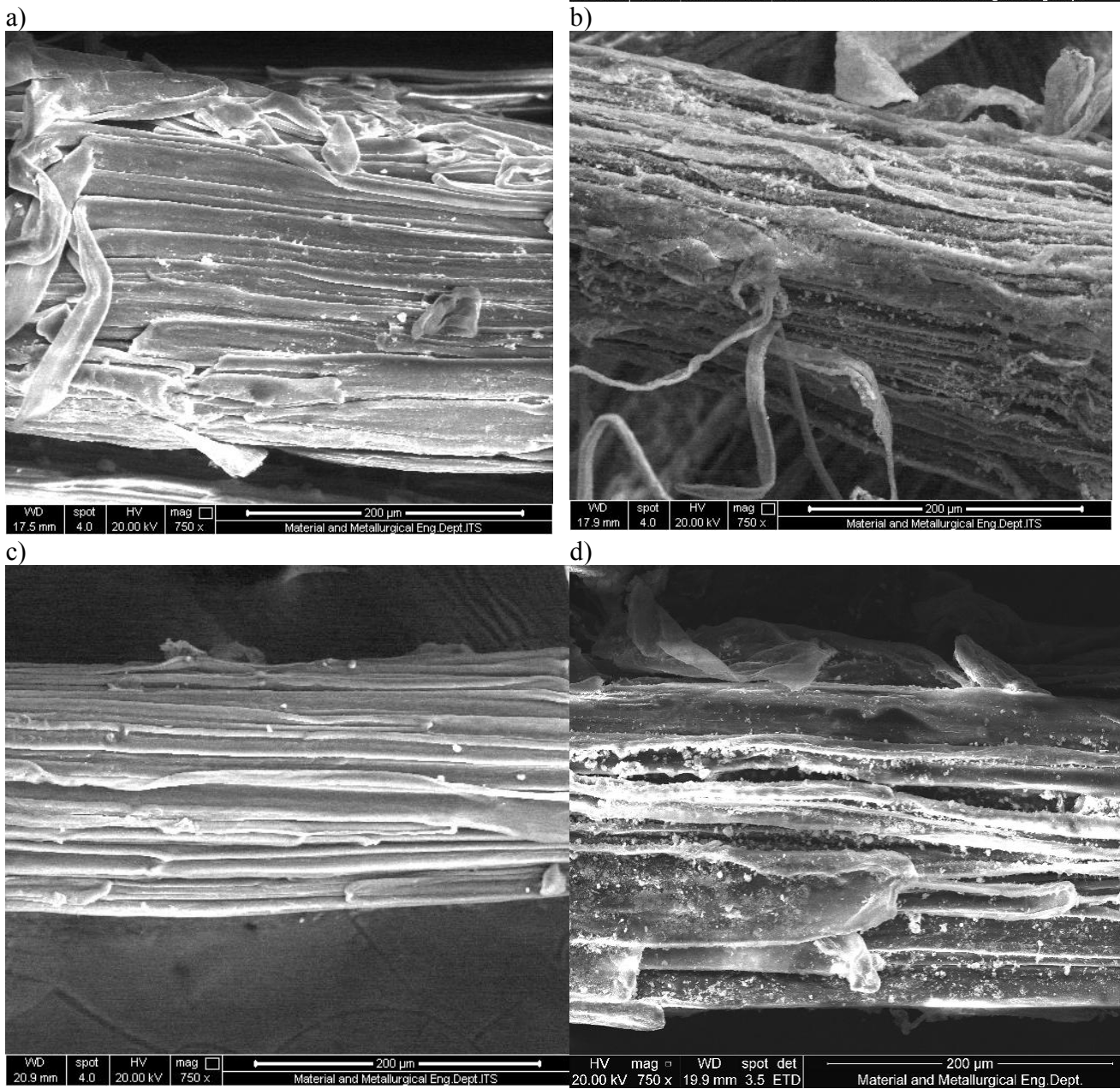

d)

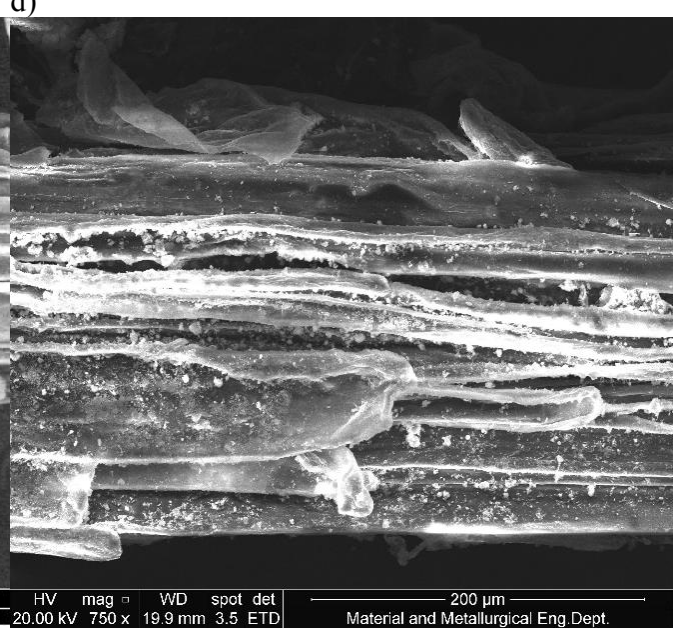

e)

f)

Fig. 5. SEM micrographs of bagasse fibers after treated using $\mathrm{NaOH}$ for a) $2 \mathrm{~h}$, c) $4 \mathrm{~h}$, and e) $6 \mathrm{~h}$ and using $\mathrm{Ca}(\mathrm{OH})_{2}$ for b) $\left.2 \mathrm{~h}, \mathrm{~d}\right) 4 \mathrm{~h}$, and f) $6 \mathrm{~h}$. 
Sugarcane fiber treated with $\mathrm{NaOH}$ for $2 \mathrm{~h}$ shows that the treatment has been able to eliminate most of the lignin and minor hemicellulose. FTIR spectroscopy detected the removal of lignin and hemicellulose (Figure 3b). The surface micrograph in Figure 5a shows a cleaner surface of the fiber compared to untreated one in Figure 4. An increase of $\mathrm{NaOH}$ treatment time to $4 \mathrm{~h}$ increases the weight loss of the bagasse from $40.5 \%$ to $45 \%$. That weight loss is evidenced by a definitive change in the morphogical structure occurred after $4 \mathrm{~h}$ treatment which the cellulose fibers observed in the micrographs in Figure $5 \mathrm{c}$ are partially decomposed. Increase treatment time in $\mathrm{NaOH}$ solution to $6 \mathrm{~h}$ increased the weight loss to $57.75 \%$. This loss was supported by FTIR spectra that reported the absence of lignin and hemicellulose spectra. Figure 5e shows deeper contour of cellulose fibers morphology compared to the fiber surface after treatment in $\mathrm{NaOH}$ for $2 \mathrm{~h}$ (Figure 5a).

SEM observations on bagasse fibers treated with $\mathrm{Ca}(\mathrm{OH})_{2}$ for $2 \mathrm{~h}$ to $6 \mathrm{~h}$ show the defibrillation of cellulose fibers. The defibrillation occurred due to the further removal of the chemical components from the bagasse. Further research is required to reveal the chemical components removed with the increase of treatment time. Figure $5 \mathrm{~b}, 5 \mathrm{~d}, 5 \mathrm{f}$ show the cellulose fibrils became more exposed. The weight loss data obtained from treatment using $\mathrm{Ca}(\mathrm{OH})_{2}$ are about $62 \%$ to $80 \%$ of the weight loss experienced by the bagasse fiber treated with $\mathrm{NaOH}$. There was an increase in weight loss about $10 \%$ to $11 \%$ with the addition of each $2 \mathrm{~h}$ treatment time. The presence of $\mathrm{CaCO}_{3}$ precipitate as it has been identified by FTIR and XRD results was evident in the SEM observation. Small particles of $\mathrm{CaCO}_{3}$ was found on the fibers surface in all treatment time (Figure 6a). Closer observation on the fiber surface (Figure 6b) shows the crystals of $\mathrm{CaCO}_{3}$ was in the initial stage of their formation with needle-like morphology and these shapes were not found anymore on longer treatment time of $4 \mathrm{~h}$ and $6 \mathrm{~h}$ treatment. The cleanliness of the fiber surface treated with $\mathrm{Ca}(\mathrm{OH})_{2}$ was not as good as the fiber surface treated with $\mathrm{NaOH}$.

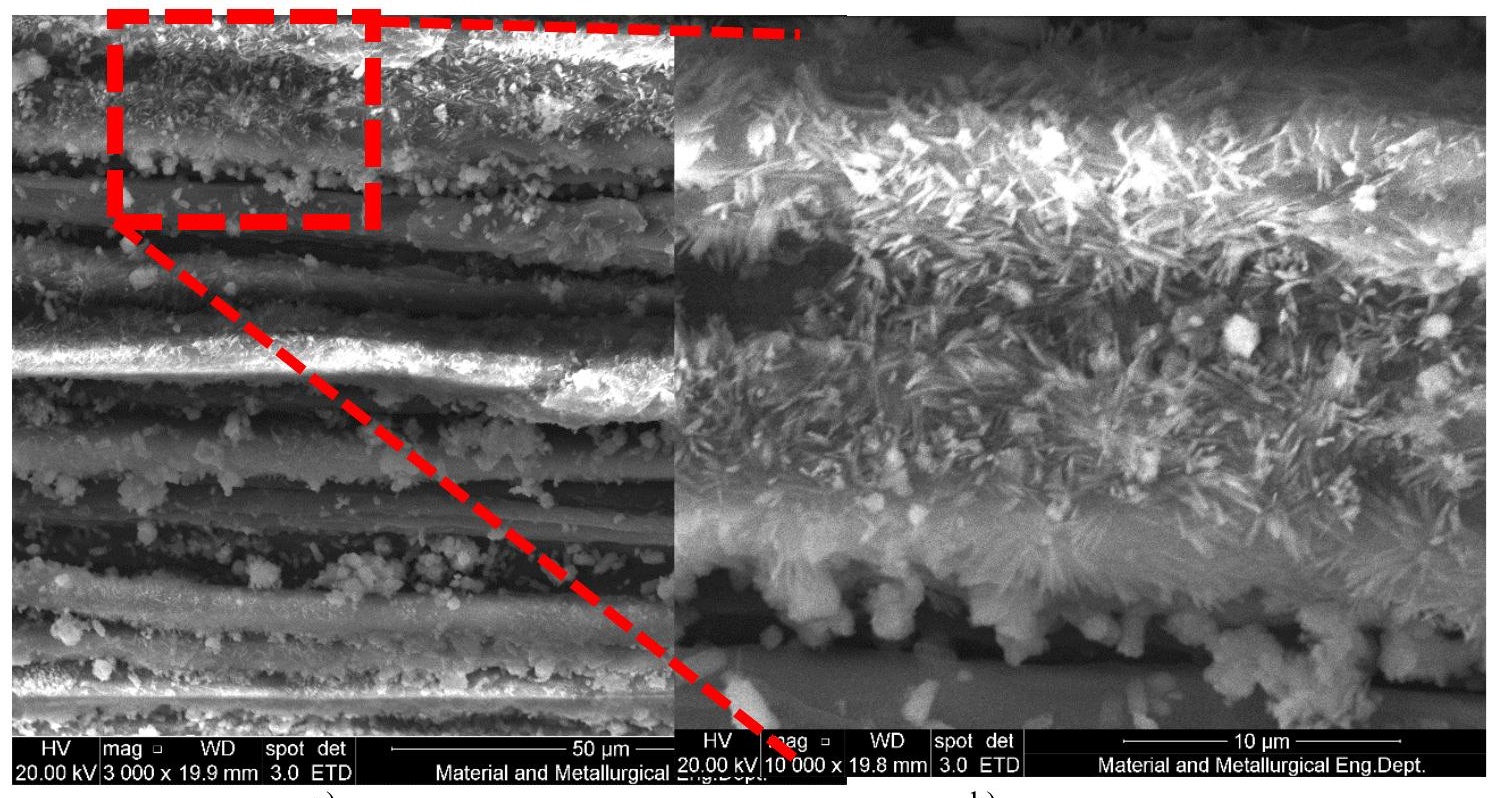

a)

b)

Fig. 6 SEM micrographs of bagasse fibers after treated with $\mathrm{Ca}(\mathrm{OH})_{2}$ for $2 \mathrm{~h}$.

The strength of the fibers after both treatments was not tested. However, their performance can be evaluated through the tensile strength of the biocomposites reinforced 
PP using both treated fibers and the results have been reported elsewhere [31]. Overall the strength of the composites using the $\mathrm{Ca}(\mathrm{OH})_{2}$ treated fibers was lower than the strength obtained using $\mathrm{NaOH}$ treated bagasse fibers.

\section{Conclusions}

Reaction of $\mathrm{Ca}(\mathrm{OH})_{2}$ with the bagasse is slower than with $\mathrm{NaOH}$. Treatment bagasse fibers using $10 \%$ vol. $\mathrm{NaOH}$ results in larger weight loss compared to treatment done with $14 \%$ vol. $\mathrm{Ca}(\mathrm{OH})_{2}$. Removal of lignin and hemicellulose was notified by FTIR in the first $2 \mathrm{~h}$ of treatment in both solutions. FTIR identified that further structural changes were not observed with the additional treatment time to $4 \mathrm{~h}$ and $6 \mathrm{~h}$. XRD spectra confirmed the transformation from cellulose I to cellulose II and identified further losses of cellulose with an increase of treatment time in $\mathrm{NaOH}$ solution. SEM evaluation on the surface morphology of the bagasse shows significant fibrillation of cellulose bundle treated with $\mathrm{Ca}(\mathrm{OH})_{2}$ with particles of $\mathrm{CaCO}_{3}$ deposited on the fiber surface.

Authors thank the Ministry of Research, Technology and Higher Education, Republic of Indonesia for the research grant under contract no. 002/SP2H/P/K7/KM/2016.

\section{References}

1. Maps of World. Top ten sugarcane producing countries in the world [Online] from https://www.mapsofworld.com/world-top-ten/sugar-cane-producing-countries.html (Accessed on 29 March 2016).

2. N. Reddy, Y. Yang. Innovative Biofibers from Renewable Resources. Verlag Berlin Heidelberg: Springer (2015). https://www.springer.com/gp/book/9783662451359

3. M.O.S Dias, A.V. Ensinasa, S.A. Nebra, R.M. Filho, C.E.V. Rossell, M.R.W. Maciel, Chem. Eng. Res. Design, 87,9:1206-1216(2009).

https://www.sciencedirect.com/science/article/pii/S0263876209001749

4. R. Katzen, D.E. Fowler, Appl. Biochem. Biotechnol., 45,1:697-707(1994). https://link.springer.com/article/10.1007/BF02941841

5. C.A. Cardona, J.A. Quintero, I.C. Paz, Bioresour. Technol., 101,13:4754-4766(2010). https://www.sciencedirect.com/science/article/pii/S0960852409015089

6. M.O.S Dias, T.L. Junqueira, O. Cavalett, M.P. Cunha, C.D.F. Jesus, C.E.V. Rossell, et al., Biosour. Technol. 103,1:152-161(2012).

https://www.sciencedirect.com/science/article/pii/S0960852411014088\#!

7. R. Rodriguez-Vazguez, G. Villanueva-Ventura, E. Riosleal, Bioresour. Technol., 39,1:17-22(1992).

https://www.sciencedirect.com/science/article/pii/096085249290051X

8. D. Verma, P.C. Gope, M.K. Maheshwari, R.K. Sharma, J. Mater. Environ. Sci.

3,6:1079-1092(2012).

https://www.researchgate.net/publication/284625466 Bagasse fiber_composites_A_R eview

9. M. Tewari, V. Singh, P. Gope, A.K. Chaudary, J. Mater. Environ. Sci.

3,1:171-184(2012). https://www.jmaterenvironsci.com/Document/vol3/17-JMES-1532011-Tiwari.pdf

10. B. Ramaraj, J. Appl. Polym. Sci., 103,6:3827-3832(2007). https://onlinelibrary.wiley.com/doi/abs/10.1002/app.25333

11. M.V. de Sausa, S.N. Monteiro, J.R.M. d'Almeida, Polymer Testing, 23:253-258(2004).

https://www.sciencedirect.com/science/article/pii/S0142941803001156 
12. J. Anggono, Á.E. Farkas, A. Bartos, J. Móczó, Antoni, H. Purwaningsih, et al., Eur. Polym. J., 112:153-160(2019).

https://www.sciencedirect.com/science/article/pii/S0014305718320317

13. Y.-T. Zheng, D.-R. Cao, D.-S. Wang, J.-J. Chen, Compos. Part A Appl. Sci. Manuf., 38,1:20-25(2007).

https://www.sciencedirect.com/science/article/pii/S1359835X06000819

14. D.R. Mulinari, H.J.C. Voorwald, M.O.H. Cioffi, M.L.C.P. da Silva, T.G. Cruz, C.

Saron, Compos. Sci. Technol. 69,2:214-219(2009).

https://www.sciencedirect.com/science/article/pii/S0266353808004119

15. Martin, J. Puls, B. Saake, A. Schreiber, Cell Chem. Technol., 45:487-494(2011). http://www.cellulosechemtechnol.ro/pdf/CCT45,7-8(2011)/p.487-494.pdf

16. P.H.F. Pereira, H.C.J. Voorwald, M.O.H. Cioffi, D.R. Mullinari, S.M.Da Luz, M.L.C.P. da Silva, Bioresour. 6,3:2471-2482(2011).

https://ojs.cnr.ncsu.edu/index.php/BioRes/article/view/BioRes_06 $3 \_2471$ Pereira_V CMDD Sugarcane Bagasse Pulp_Bleach Thermal_Chemical

17. C.C. Geddes, J.J. Peterson, C. Roslander, G. Zacchi, M.T. Mullinnix, K.T.

Shanmugam, et al., Bioresour. Technol., 101:1851-1857(2010).

https://www.sciencedirect.com/science/article/pii/S0960852409013200

18. G.J.D.M. Rocha, C.M. Medina; I.B. Soares, A.M.S. Maior, H.M. Baudel, C. A.M. de Abreu, Biomass Bioenerg., 35,1:663-670(2011).

https://www.researchgate.net/publication/251628703 Dilute mixedacid pretreatment of sugarcane bagasse for ethanol production

19. S.M. Luz, A.R. Gonçalves, A.P. Del'Arco, Compos. Part A: Appl. Sci. Manuf., 38:1455-1461(2007).

https://www.sciencedirect.com/science/article/pii/S1359835X07000206

20. J.M. Paturao. By products of the cane sugar industry, an introduction to their industrial utilization. New York: Elsevier Scientific Publication Company (1982). https://trove.nla.gov.au/work/8292736?selectedversion=NBD2110076

21. P.F.H. Harmsen, W.J.J. Huijgen, L.M.B. López, R.R.C. Bakker. Literature review of physical and chemical treatment processes for lignocellulosic biomass. Netherland:

BioSynergy Project (2010).

https://www.researchgate.net/publication/254853217_Literature Review of_Physical and Chemical_Pretreatment_Processes for_Lignocellulosic Biomass

22. G.J. de MoraesRocha, V.M. Nascimento, A.R. Gonçalves, V.F.N. Silva, C. Martín, Ind. Crop. Prod. 64:52-58(2015).

https://www.sciencedirect.com/science/article/pii/S092666901400689X

23. C.A. Rezende, M.A. de Lima, P. Maziero, E.R. de Azevedo, W. Garcia, I. Polikarpov, Biotechnol. Biofuels 4,54:1-18(2011).

https://biotechnologyforbiofuels.biomedcentral.com/articles/10.1186/1754-6834-4-54

24. J. Biagiotti, D. Puglia, L. Torre, J.M. Kenny, A. Arbelaiz, G. Cantero, et al., Polym.

Composite, 25,5:470-479(2004).

https://onlinelibrary.wiley.com/doi/abs/10.1002/pc.20040

25. W. Liu, A.K. Mohanty, L.T. Drzal, P. Askel, M. Misra., J. Mater. Sci., 39:1051-1054(2004).

https://link.springer.com/article/10.1023\%2FB\%3AJMSC.0000012942.83614.75

26. Y. Chen, R.R. Sharma-Shivappa, D. Keshwani, C. Chen. Appl. Biochem. Biotechnol., 142,3:276-290(2007). https://www.ncbi.nlm.nih.gov/pubmed/18025588

27. O. Sauperl, K. Stana-Kleinschek, V. Ribitsch, Text Res J., 79,9:780-791(2009). https://journals.sagepub.com/doi/abs/10.1177/0040517508096222?journalCode=trjc 
28. G.T. Ciacco, D.L. Morgado, E. Frollini, S. Possidonio, O.A. El Seoud, J Braz. Chem Soc. 21,1:71-77(2010).

http://www.scielo.br/scielo.php?script=sci_arttext\&pid=S0103-50532010000100012

29. E. Dinand, M. Vignon, H. Chanzy, L. Heux, Cellulose 9,1:7-18(2002). https://link.springer.com/article/10.1023/A:1015877021688

30. L. Chenxi, Using anaerobic co-digestion with addition of municipal organic wastes and pre-treatment plant sludge. [Thesis Phd]. Queen's University Kingston, Ontario, Canada (2012), p. 105.

https://qspace.library.queensu.ca/bitstream/handle/1974/7487/Li_Chenxi_201209 PH D.pdf?sequence $=1$

31. J. Anggono, S. Sugondo, S. Sewucipto, H. Purwaningsih, S. Henrico, AIP Conference Proceedings 1788,1:1-9(2017). https://aip.scitation.org/doi/10.1063/1.4968308 